\title{
Collective Bargaining Worker Union of Fspsi Surabaya: Study on Concept and Practice of Industrial Relation
}

\author{
Ahmad Rizki Sridadi \\ $\mathrm{Ph} . \mathrm{D}$ Candidate in Management at Faculty of Economics and Business \\ Universitas Padjadjaran
}

Doi:10.5296/ijhrs.v4i4.6713

URL: http://dx.doi.org/10.5296/ijhrs.v4i4.6713

\begin{abstract}
The purpose of this paper is to examine collective bargaining (negotiation) exercised by worker union as the attempt to arrange collective agreement from the aspect of: concept and approach, Indonesia regulation, and practices by working unit official (PUK) under all Indonesia worker union (SPSI) in Surabaya. This paper applies qualitative exploratory method with case study approach by which data collection was implemented through structured interview, observation and literature review. The implication of this paper is its contribution in literature reaching concerning principles, techniques, approaches, and process of collective bargaining both in conceptual and empirical side. Besides, practical implication is for company and working unit official as learning material in subsequent collective bargaining. This paper reveals variations among practices and its concordance with the relevant concept and implementing regulations.
\end{abstract}

Keywords: collective bargaining, collective agreement, worker union, SPSI

\section{INTRODUCTION}

Industrial relation includes 3 elementary parties, namely: government, employer, and worker union. Activities that have frequently been involved within those parties are negotiation by which various employment issues are handled and settled. Several crucial issues concerning employment that needs negotiation are social security fulfillment, local/regional regional wage, employment termination, health and safety of work, and other political and economic rights.

In general, each parties in terms of tripartite within industrial relation set some efforts to satisfy their vital interests that are (Simanjuntak, 2009:5-7) from employer side is to: secure its entire assets, capitalize investment, increase profit and welfare of employer; from worker interests is: to get employability, to be source of income, as instrument to have self-training and experiences enrichment, and place to foster career; and from government points of view 
are as: source of society income, medium of economic growth, source of state income.

In this paper, among those parties negotiation is limited to employer and worker and is meant as collective bargaining as the instrument for both sides to meet and to create shared interests in terms of employment in workplace (company). One of strategic forms of interests of worker union in workplace is collective agreement (PKB: perjanjian kerja bersama). Therefore, collective agreement is one of pillars as effort of worker union to achieve its raison d'etre. Moreover in the era when competitiveness among companies rise that require conflicts reduction between company and worker in order to be superior in goods and services delivery (Gatchalian, 1998).

However, the portrait of $\mathrm{PKB}$ achievement as the result of collective bargaining has not indicated the ideal level yet and in this paper the relevant achievement in east java companies is illustrated in subsequent Table 1.

Table 1

Global Condition of Collective Agreement (PKB) in East Java 2009-2011

\begin{tabular}{ccccccc}
\hline $\begin{array}{c}\text { MEDIUM/ } \\
\text { YEAR }\end{array}$ & \multicolumn{2}{c}{2009} & \multicolumn{2}{c}{2010} & \multicolumn{2}{c}{2011} \\
& $\begin{array}{c}\text { Potenti } \\
\text { al }\end{array}$ & Real & Potenti & Real & Potenti & Real \\
& 2.453 & 837 & 2.453 & 1.976 & NA & 418 \\
\hline
\end{tabular}

Source: Modified from the Report of Agency of Manpower, Transmigration, and Demography of Province of East Java Year 2009 and 2010 and Data Company Regulation (PP) and PKB Province of East Java 2009-2012

The level of achievement of PKB refered in Table 1 indicates the problem of collective bargaining effectiveness that is attempted to be attained by worker union as instrument to have basic interests of worker union and company. Therefore, collective bargaining become interesting issue to be examined in this paper particularly in the variety of collective bargaining, applied approach, prevailed regulation, and collective bargaining practices of worker unions under federation of all Indonesia worker union (FSPSI) in East Java, Indonesia. Research questions that are posed in this discussion are: firstly, how is the development of concepts, principles, and process of collective bargaining; secondly, how Indonesia regulations explain collective bargaining; and thirdly how are the practices and experiences of PUK of worker union in implementing collective bargaining process. This paper is aimed not only to have various perspective of the type of collective bargaining employed by several PUK and also to have the more effective type of collective bargaining that is acceptable and can be implemented in workplaces.

\section{LITERATURE REVIEW}

The terms collective bargaining and negotiation in this paper will be used interchangeably with same definition namely the methods of decision making employed by parties to meet their position of policies when disagreement is happened concerning the intended result 
(Heldt, 2006). Another definition of collective bargaining is as process envelopes negotiation, drafting, administration, and interpretation over written agreement between worker union and employer for specified period of time (Byars and Rue in Edralin, 1999). While Lobel (2000) defined collective bargaining as "a process in which the management and a union representing employees sit down and negotiate over wages, hours, and working conditions".

Collective barganaing constitutes one of forms of essential relationship between worker and employer so that their relationship is multidimension in nature and creates diverse types of relationship. Those types of relationship embodies in at least 2 styles that are by Scarth (in Edralin, 1999) identified as: firstly, adversarial, between worker union and employer during negotiation; secondly, cooperation that includes cooperation between both parties to make an agreement.

The other concept stated by Armstrong (Hargrove, 2010) that identified 4 styles in negotiation in more detail as illustrated in subsequent Table.

Table 2

Styles of Relationship between Worker - Employer

\begin{tabular}{|c|c|}
\hline Traditional & Power Sharing \\
\hline Adversarial & Partnership \\
\hline
\end{tabular}

Source: Armstrong in Hargrove (2010) adjusted

From Table 2, it could be drawn concise explanation that adversarial type is characterized by the dispute between employer and worker(s). Power sharing is style where workers involved in operational and decision making. Afterwards traditional style indicated by high initiative of employer that is responded by worker union. Lastly, partnership in which employer actively includes worker(s) in formulating company policies within employer control. Hargrove (2010) postulated that collective bargaining could be arranged in the environment with traditional and partnership styles.

Conceptually, collective bargaining has diverse perspectives delivered by several scholars. Initially, collective bargaining concept known as traditional adversarial bargaining (Armstrong in Hargrove (2010)). This kind of bargaining, Armstrong continued, contained 4 phases namely: firstly, preparing of negotiation; secondly, opening; thirdly, bargaining; and fourthly, closing. Short explanation of those phases is begun with bargaining strategy determination and data collection. This first phase is then continued with opening phase consisting of delivering bargaining intention and other important issues followed with interest exchange/strategic concession of both parties. This process has negative character containing disputes which in turn ends in agreed result as a remark of closing phase. This traditional bargaining concept is known as hard approach (Lens, 2004).

Parallel with Armstrong's first phase is Budiarti's namely preparation which included aspiration and needs of worker (s) and employer collection activities and setting of agenda and negotiation team. The next phase was arranging demands of worker(s) and employer that 
was continued with application of technic "if-then" to avoid, resist, or approve of something. Afterwards negotiation was conducted with technic "I will if you will" followed with efforts to agree principles of PKB. Negotiation process ended as agreement occured marked with agreement draft to be signed, implemented, and socialized to each party.

It was different with Armstrong's and Budiarti's (2005) that commenced bargaining with data collection and strategy formulation, concept of labor-Management Collaboration from Rubin and Rubin (2006) suggested to previously collect external and internal demands along with the meaning of bargaining for both parties (impetus stage), followed with identification and finding of differences and sameness of purposes and needs which required cooperation and agreement (initiation stage). Subsequently, worker union play the role of representing and protecting worker(s) as negotiating with employer according to shared interests and therefore training was necessary (implementing stage). On the stage of integration, worker union and employer strengthened their commitment and gathered support from each party towards collaborative efforts within bargaining process. Lastly, collective agreement could be gained.

By definition, interest-based bargaining is a negotiation process to solve problem conducted creatively to mainting relationship between employer and worker(s) (Brainerd, 1998). Interest-based bargaining was also known as win-win bargaining, concensus bargaining, problem-solving bargaining, and collaborative bargaining (Beil and Litscher, 1998).

When Rubin and Rubin's (2006) placed the process of meaning as beginning of bargaining process, Post (1990) provided time frame and activities setting on each intended time/period. He offered the meeting of employer and worker union 1 year before the end of PKB and commitment strengthening between both parties for the next 6 months. Entering explanation phase 1 month since the expiration of PKB, employer and worker union submit proposal for one to another. The next 2 weeks both parties distributed questionnaires to all workers as a mark of validation stage. Based on the result of questionnaires, both parties obtained issues that had been priority in negotiation stage. In this stage, mediator was involved in bargaining process that ended in agreement, disagreement, or other alternative solutions.

Besides, collective bargaining which is named as consensus bargaining by Beil and Litscher (1998) was detailed into 4 phases, namely: firstly, all bargainers identified all mutually beneficial interests as constructive basis to commence discussion; secondly, negotiation team, furthermore arranged series of options to fulfill the needs of parties; thirdly, following position determination all negosiators agreed the criteria to review the existing options; and fourthly, all negotiators applied standard and identified options that may become concensus. Additionally, in wisconsin case, there exists combination (hybrid) in the form of facilitation and mediation through for instance: the development of self-facilitation between parties while lessened the roles of outside facilitator. This new form of bargaining required wide experience of all negotiators; summarized some initial processes in accelerating negotiation process; and authority in taking decision by all negotiators, apart from the their leader. 


\section{Mll Macrothink}

The concept of time-frame bargaining including working agenda inside other than Rubin and Rubin (2006) was also used by Finishing Contractors Association and Allied Traders International Union (FCA \& ATI Union). FCA \& ATI Union divided bargaining process into 3 stages which was commenced with preparation stage. This stage was exercised 18 months before the expiration of PKB through administering informal discussion concerning issues such as the evaluation of previous negotiation and reviewed matters, expectation, and agenda which could be resolved in advance before conducting formal negotiation. 12 months before expiration of $\mathrm{PKB}$, all essential matter was discussed such as allocation schedule, type of negotiation, and other important matters that would be discussed within negotiation. The subsequent stage was the implementation of negotiation namely submission of proposal, noting important matters that had been dicussed and agreed, and the possibility of the involvement of third party. This bargaining process was ended with agreement ratification and communication to all related parties.

Negotiation in any purposes including to have PKB between employer and worker(s) not only rely on technic and knowledge of negotation materials as the understanding of directives for all parties are mandatory to be mastered especially to build a noble negotiation. Lens (2004) as cited Fisher et al. (1991:4) offered principled negotiation which ends to a "wise agreement...which meets the legitimate interests of each side to the extent possible, resolves conflicting interests fairly, is durable, and takes community interests into account" . they identified several essential principles of principled negotiation: firstly, ability to separate person from problems; secondly, focus on interest not position; thirdly, collection of as many as alternative solution for common good; and application objective criteria. Other than those principles, it is importantly considered to avoid: deception, bluffing, concealment, distortion, conscious misstatement, and lies as types of action which could disparage ethical values (Provis, 2000).

In guiding collective bargaining process for the best interest of both parties, other requisite principles must be considered namely: firstly, admission of conflicting interests between employer and worker(s); secondly, resolution of disputes through compromising between worker(s) demands and employer proposal; thirdly, without violence; and autonomy in bargaining. 
Table 3

Comparing Different Styles of Negotiation

\begin{tabular}{|c|c|c|}
\hline Hard & Soft & Principled \\
\hline Participants are adversaries & Participants are friends & $\begin{array}{l}\text { Participants are problem } \\
\text { solvers }\end{array}$ \\
\hline $\begin{array}{l}\text { There is only one solution to } \\
\text { the problem }\end{array}$ & $\begin{array}{l}\text { The solution is the one the } \\
\text { other side will accept most } \\
\text { readily }\end{array}$ & $\begin{array}{l}\text { There are several solutions to } \\
\text { the problem }\end{array}$ \\
\hline $\begin{array}{l}\text { The goal is winning at any } \\
\text { cost }\end{array}$ & $\begin{array}{l}\text { The goal is agreement that } \\
\text { may sometimes involve } \\
\text { one-sided losses }\end{array}$ & $\begin{array}{l}\text { The goal is reaching a } \\
\text { mutually } \\
\text { agreement }\end{array}$ \\
\hline $\begin{array}{l}\text { Threats and personal attacks } \\
\text { are appropriate }\end{array}$ & $\begin{array}{l}\text { Conciliatory and friendly } \\
\text { gestures and concessions are } \\
\text { frequently used }\end{array}$ & $\begin{array}{l}\text { The problem, not the people, } \\
\text { is the focus }\end{array}$ \\
\hline $\begin{array}{l}\text { Distrust and suspicion is } \\
\text { assumed }\end{array}$ & ssumed & d independent of trust \\
\hline $\begin{array}{l}\text { Misleading and distorting } \\
\text { position are appropriate }\end{array}$ & $\begin{array}{l}\text { Positions are changed easily } \\
\text { and often to satisfy the other } \\
\text { party }\end{array}$ & $\begin{array}{l}\text { Positions are based on fair } \\
\text { and objective standards }\end{array}$ \\
\hline $\begin{array}{l}\text { Compromise } \\
\text { acceptable }\end{array}$ & $\begin{array}{l}\text { Concessions are made to } \\
\text { encourage a } \\
\text { relationship and to avoid } \\
\text { conflict }\end{array}$ & $\begin{array}{l}\text { Compromise is appropriate } \\
\text { when based on principle, not } \\
\text { pressure }\end{array}$ \\
\hline
\end{tabular}

Source: Fisher et al. (1991:9,13) as cited by Lens (2004)

Brainerd (1998) explained another type of interest-based bargaining conducting by parties, namely: manpower director, county manager, labor relations manager, and 2 business agent of American Federation of State, County, and Municipal Employees (AFSCME). This type of bargaining also included outside negotiator. In the beginning, series of meeting were implemented among business agent, worker union, and manpower director to put basis of cooperation in place. Activities were continued with the preparation of bargaining in the form of communication training and team development for both sides (employer and worker union) and training on bargaining definition, its purposes, process implemented, and technic in developing concensus. Furthermore, each party identified and developed issues and interests within negotiation process taking place during 3 weeks in resulting alternative problem solving based on collaborative spirit. After that, evaluation was practiced for deciding whether interests of all parties had been accomodated. The alternative problem solving that had been evaluated and agreed was then become part of shared collective agreement.

Edralin (1999) explained 3 main phases of collective bargaining to make collective bargaining agreement (CBA) extracted from cases of companies that become samples in which the implementation was begun with pre-negotiation phase. This phase stated formulation of demands in the form of CBA draft during 60 days before expiration of existing 
CBA. Other than CBA draft, worker(s) needs demanded was responded by employer in written. In the phase of negotiation occured the submission of demands of both parties along with strategy determination for obtaining provisions that could be beneficial for each party to achieve agreement. The signing of CBA by both parties required the implementation of prevailing $\mathrm{CBA}$ for certain period of time and this marking the implementation of $\mathrm{CBA}$ phase.

Introduction activities within informal atmosphere by both parties precedes general review phase as explanation attempt of each party including interest and their interests was part of concept of Guntur (2010). Furthermore, both parties evaluated and conceived issues that was delivered and then explained realistic matters that could be settled in advance. On negotiation phase, both parties exchanged their concession with intention to acquire solutive information. In order to maintain orderliness of the exchange of concession, both parties should compromize or involve mediator. The result of compromy phase was an agreement.

Of many existing concepts in achieving certain result, interest-based bargaining offers advantage namely fulfilment of interests underlying both parties rather than traditional concept (Roose, 2006). Other advantages of interest-based bargaining are as follow: firstly, bringing changes in collective agreement; secondly, producing financial concession more than traditional bargaining towards shared benefit; thirdly, asssisting company adapted more to environmental changes (Paquet et al., 2000). Thereby, Paquet et al. (2000) stated, interest-based negotiation produces more positive changes for both parties though it could bring more concession but less gains within PKB for worker union.

However, interest-based bargaining is not perfect concept in industrial relation (Lobel, 2000). He continued that this concept was slightly different with approach and technic of other types of bargaining such as traditional or adversarial as the ultimate point for negotiator was flexibility and creativity towards needs and basic interests between negotiator and person negotiator negotiates.

Determining factors to the success of collective bargaining depend not only to the process as the surrounding situation that affects negotiation and position during negotiation should be considered. According to Heldt (2006), there exists 2 kinds of situation contributing to the implementation of bargaining namely: firstly, situation of integrative bargaining as polarisation takes place or the power of both sides is torn apart, less number parties involved, only several policies negotiated, there is coalition building process, and existing way or instrumen to achieve agreement. Donohue and Roberto (1996) explained distributive process happened as one acted creatively along with effort in heightening capacity to have shared result; secondly, situation of distributive bargaining explaining that only one policy that was negotiated and party with weaker position get some parts of agreement though this type of process might lead to rigid situation. Furthermore, within integratif collective bargaining, Caverley, Cunningham, and Mitchell (2006) argued, conditions may affectt the success of implementation: firstly, the trust level of parties; secondly, negotiator style; thirdly, the clarity 
of bargaining materials; and fourthly, ability of facilitator in applying problem solving technic.

\section{Models of Negotiation in The Position of Distributif and Position of Integratif}

In distributive and integrative situation, all parties may take some positions ot models as strategies intended to achieve their goals. The following 3 models of Donohue and Roberto (1996) could be used in the relevant situation. Through separate model, all parties set some goals at the beginning of the negotiation and implemented it according to issue, strategy, and tactics. In the situation of distributive, all parties put the economic issue and took face to face position negtive. If integrative situation occured, they set various issues including the resolution and behavior that support common success.

In the stage model, generally all negotiators began with distributive position and continued with integrative position stressing on settlement, strategies, and supporting tactics. Interdependence model contained relatedness between position of integrative and position of distributive. Both was practiced interchangeably at sequential periode during negotiation so that negotiator may resist another's arguments and at the same time develop constructive ways. In this way, it is hard to determine whether negotiator was taking distributive or integrative position.

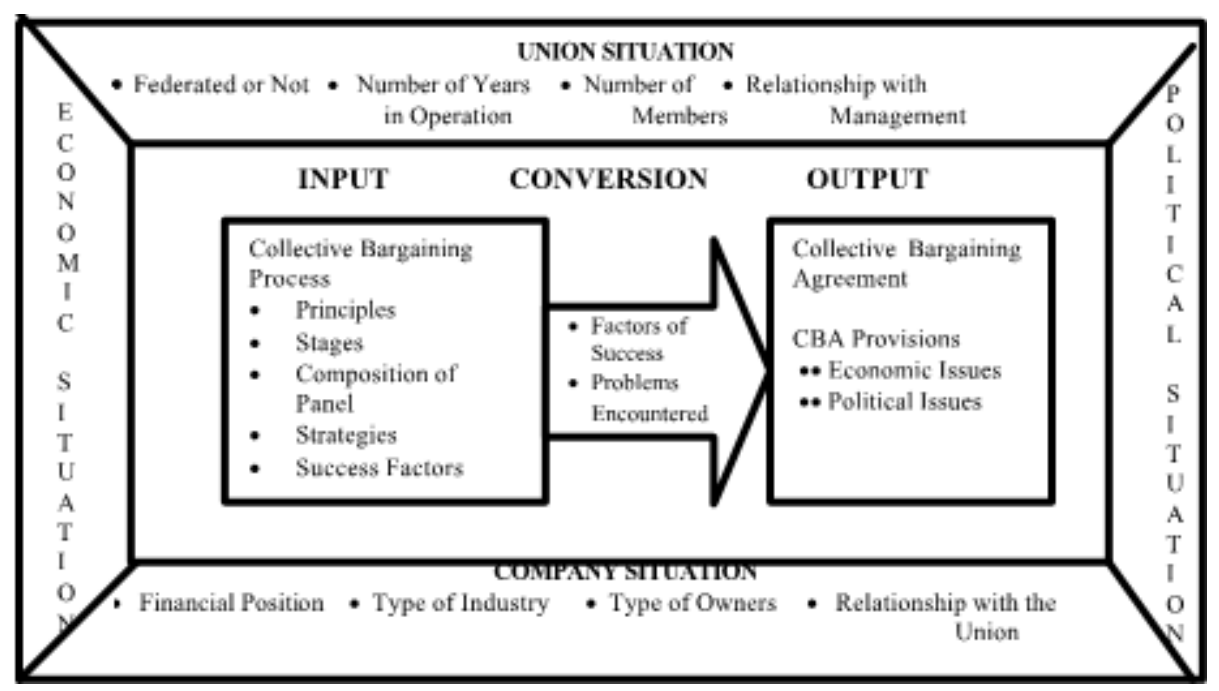

Picture 1. The Scheme of the Process of Collective Bargaining

Source: Edralin (1999)

\section{Strategy of Negotiation}

All parties, during negotiation, may have 4 ways as strategy in achieving goals. Arbono as cited by Guntur (2010) identified the intended strategy: 1. Win-win, trough this strategy all parties prioritize dispute resolution that is simbiosis mutualism; 2. Win-lose, by which all parties set competitive situation to get maximum results on one side and the maximum losses on another side; 3 . Lose-lose, through this strategy all parties do not reap the fruit as a result 
of the mistake in choosing strategy; 4. Lose-win, selection of this strategy is based on one side that deliberately give way to get benefits through this strategy.

\section{The Regulations concerning Collective Bargaining in Indonesia}

Besides reviewing collective bargaining conceptually according to literatures, it is important to discuss the normative aspect of collective bargaining that is useful in broadening the relevant perspective and getting new ways that may lead to effective collective bargaining.

Collective bargaining in Indonesia as stipulated in the regulation of Minister of Manpower and Transmigration of Republic of Indonesia Number PER.16/MEN/XI/2011 concerning The Procedures of Making and Ratification The Company Regulation and The Making and The Registration of Collective Agreement (Permenaker Number 16 Year 2011). Permenaker Number 16 Year 2011 regulates that the phases of collective bargaining is stipulated from art. 12 to art. 26. These articles briefly states that negotiation process is conducted by worker union and several worker unions that have been recorded at agency of manpower affairs with employer and several employers through meeting with duration of negotiation is determined based on concensus between parties written in negotiation provision. Principles that are used in the negotiation of PKB are: 1. Good faith, and 2. Free will of both parties.

Negotiation of making PKB is begun with the provision of negotiation containing: a. Purpose of making provision of negotiation; $b$. The formation of negotiating team; c. Duration of negotiation; d. Materials of negotiation; e. Place of negotiation; f. Ceremony of negotiation; $g$. Resolution procedure if deadlock occured; h. Validity of negotiation; and i. Cost of negotiation. Permenaker Number 16 Year 2011 does not explain any further activities during negotiation and setting the certain stipulation if the negotiation of PKB making does not finish timely. In this event, both parties may reschedule the subsequent negotiation in 30 days after the failing negotiation and if fail again then both parties should make statements concerning the unfinished negotiation for being recorded at agency of manpower affairs that will be acting as mediator. The ending of negotiation is marked with the failing of mediator in settling the PKB negotiation by both parties untill the filing of suit to the court of industrial relations. 
The following Table 4 consists of the varieties of collective bargaining types:

\section{Table 4}

The Summary of The Varieties of Collective bargaining

\begin{tabular}{|c|c|c|c|c|}
\hline $\begin{array}{l}\text { Collaborative } \\
\text { Collective } \\
\text { Bargaining } \\
\text { (Post, 1990) } \\
\end{array}$ & $\begin{array}{l}\text { Alternative Model } \\
\text { of Interest Based } \\
\text { Bargaining } \\
\text { (Brainerd, 1998) } \\
\end{array}$ & $\begin{array}{c}\text { Consensus } \\
\text { Bargaining } \\
\text { (Beil and } \\
\text { Litscher, 1998) } \\
\end{array}$ & $\begin{array}{c}\text { Negotiation } \\
\text { (Edralin, 1999) }\end{array}$ & $\begin{array}{c}\text { Traditional } \\
\text { Bargaining } \\
\text { (Armstrong in } \\
\text { Hargrove 2010)) }\end{array}$ \\
\hline $\begin{array}{l}\text { 1. Commitment } \\
\text { 2. Explanation } \\
\text { 3. Validation } \\
\text { 4. Prioritization } \\
\text { 5. Negotiation }\end{array}$ & $\begin{array}{l}\text { 1. Holding } \\
\text { meetings for } \\
\text { basic } \\
\text { cooperation } \\
\text { 2. Communication } \\
\text { training and } \\
\text { other aspects of } \\
\text { bargaining } \\
\text { 3. Interests } \\
\text { 4. Evaluation and } \\
\text { consensus for } \\
\text { PKB }\end{array}$ & $\begin{array}{l}\text { 1. Identification } \\
\text { all interests } \\
\text { 2. Arranging } \\
\text { options for } \\
\text { fulfilling the } \\
\text { parties' needs } \\
\text { 3. Agreement } \\
\text { on criteria to } \\
\text { review options } \\
\text { 4. Indentification } \\
\text { of options for } \\
\text { consensus }\end{array}$ & $\begin{array}{l}\text { 1. Pre negotiation } \\
\text { 2. Actual } \\
\text { Negotiation } \\
\text { 3. Implementation } \\
\text { of CBA }\end{array}$ & $\begin{array}{l}\text { 1. Preparation } \\
\text { for } \\
\text { negotiation } \\
\text { 2. Opening } \\
\text { 3. Bargaining } \\
\text { 4. Closing }\end{array}$ \\
\hline $\begin{array}{c}\text { Labor-Management } \\
\text { Collaboration } \\
\text { (Rubin dan Rubin, } \\
\text { 2006) }\end{array}$ & $\begin{array}{c}\text { Negotiation } \\
\text { (Guntur, 2010) }\end{array}$ & $\begin{array}{l}\text { Permenaker No. } \\
16 \text { Tahun } 2011\end{array}$ & $\begin{array}{c}\text { Negotiation } \\
\text { (Budiarti, 2012) }\end{array}$ & $\begin{array}{c}\text { Bargaining } \\
\text { Process } \\
\text { (FCA \& ATI } \\
\text { Union, No } \\
\text { Year) }\end{array}$ \\
\hline $\begin{array}{l}\text { 1. Impetus } \\
\text { 2. Initiation } \\
\text { 3. Implementation } \\
\text { 4. Integration } \\
\text { 5. Institutionalisation }\end{array}$ & $\begin{array}{l}\text { 1. Introduction } \\
\text { 2. General Review } \\
\text { 3. Background } \\
\text { 4. Explanation of } \\
\text { Problem } \\
\text { 5. Negotiation } \\
\text { 6. Compromize } \\
\text { 7. Resolution }\end{array}$ & $\begin{array}{l}\text { 1. Consensus of } \\
\text { Negotiation } \\
\text { provisions } \\
\text { 2. Negotiation } \\
\text { 3. The } \\
\text { Completion of } \\
\text { Negotiation }\end{array}$ & $\begin{array}{l}\text { 1. Preparation } \\
\text { 2. Formulation of } \\
\text { Demands } \\
\text { 3. Ways of } \\
\text { Problem } \\
\text { Resolution } \\
\text { 4. Negotiation } \\
\text { 5. Agreement } \\
\text { 6. Implementation } \\
\text { of Agreement }\end{array}$ & $\begin{array}{l}\text { 1. Preparation } \\
\text { for } \\
\text { Bargaining } \\
\text { 2. Conducting } \\
\text { Contract } \\
\text { Negotiations } \\
\text { 3. Post } \\
\text { Bargaining } \\
\text { Events and } \\
\text { Communicat } \\
\text { ions }\end{array}$ \\
\hline
\end{tabular}

\section{The Review of The Practice of Collective Bargaining}

In order to have wider horizon on collective bargaining, the focus is not only to conceptual-normative assessment but also reviewing on practices of worker union in managing human resources to get PKB. The implementation of conceptual-normative review takes the view of "what should be" (de jure) but it is required to be equipped with necessary 
experiences by the negotiationg actors of worker unions from the view of "what the fact is" (de facto). Therefore, it is important to understand the implementation of negotiation conducted by several worker unions in Surabaya under FSPSI in which in this paper is begun with the illustration of negotiation of PUK PT. WS FSPSI cigarette, clove, and beverage (RTMM) followed by PUK PT. IP FSPSI metal, electronic, and machine (LEM) based on interview carried out by the officers of both PUK.

\section{PUK PT. WS FSPSI RTMM}

Negotiation process involved company party that was represented by general manager (it was called human resource manager) along with its team/group and worker party represented by chair, secretary, and team consisting of spokeperson team, data processing team, and data seeking team. Of 2 companies, there existed 2 worker union that merges into 1 team for each sending 7 persons as representation. Besides, each of position of chair and secretary occupied by 2 persons so that there existed 2 chairs and 2 secretaries while other persons become part of 3 other existing teams. Outside party as consultan for negotiation to any party was allowed but in fact the relevant consultant was not directly involved in negotiation process.

Entering negotiation process, both parties observed draft of negotiation main materials that includes issues and interests of each party, especially issue of worker welfare. Both parties conducted discussion and bargaining supported with relevan data. Inventory/collection of agreed and disagreed materials were brought to agency of manpower. Agreement marked ending of this negotiation process. After achieving agreement, the next phase was collective agreement $(\mathrm{PKB})$ recording by Agency of manpower city of Surabaya and socialization of $\mathrm{PKB}$ to all members.

During negotiation, it is known that worker union representation did not get training in supporting negotiation but PUK worker union enhanced capacity of the representative through involvement of senior worker that was asked for explaining his/her experiences and certain technics for negotiation success. Principles of negotiation had been known and implemented during negotiation namely: 1. Prevention from lobbies before and during negotiation to all representatives; 2. Emotion controlling during negotiation.

\section{PUK PT. IP FSPSI LEM}

Negotiation in this workplace was limited only to 2 parties namely, PUK and employer. Whereas outside party especially agency of manpower was included in negotiation if disputes arised untill postponing the negotiation. Both parties conducted negotiation in the workplace (company) where PUK come from by considering determinant factors such as eficiency.

Negotiation that was conducted in workplace consisted of 3 phases. First phase, 2 or 3 months before the expiration of PKB, each employer and PUK discussed internally among its officers on PKB contents draft, which was then the relevant PKB drafts from both parties 
were exchanged one to another. For ensuring the validity of each persons as all parties representatives, persons of each team must have decree containing negotiating team for negotiation matters. After internal discussion, PKB proposed that negotiation was conducted 1 or 2 months before PKB was expired. If response of employer over the proposal come close to the expired date so that negotiation would pass over then the former PKB would prevail if there would be any disputes. this decision was taken to anticipate the vacuum of law if agreement could not be reached as PKB had been expired. In the negotiation phase was discussed the contents (articles) of PKB while the conflicting articles might bring to agency of manpower. In contrary, if agremeent occured then both parties signed the PKB and recorded in meeting doument. This negotiation phase took place within 30 days. After signing, documenting, and registering to agency of manpower, PKB was in effect.

For the interest of negotiation, PUK did not train its members but having consultation to worker union branch representative (city/district level) to discuss solution for win-win solution. Moreover, during negotiation PUK should consider ethical values as basic principle.

\section{CONCLUSION, SUGGESTION, AND LIMITATION}

Several explained concepts on collective bargaining points out the varieties of negotiation process formulated by scholars may be different according to location, context, situation, and each of workplace character. The needs and demands to apply one or combination of those types of negotiation including the chosen strategies and situation (position) may be resulted from observation and assessment by one party i.e. worker union.

Those differences was mirrored by varieties of negotiation type that were practiced by several PUK FSPSI in Surabaya city. No above concepts or regulation that were employed per se by worker union. However, worker union used negotiation with general time frame including implementation of pre negotiation phase though there was no training in supporting negotiation knowledge and skill yet. The level of complexity of negotiation phases and materials very depended on the experiences, kowledges, abilities, and preference of the leader and its team members, and also burgeoning situation. The prevailing regulations related to negotiation was also not used appropriately considering the function of regulation as directive of action for regulated person.

In light of PKB constitutes essential medium and also rights of every worker union then though practice variety may be dissimilar but it is actually needed process of making PKB with minimal standard in the aspect of phases, time, contents (articles), negotiation structure team of worker union, knowledge, skill, and behavior. However, it is advised to avoid adversarial style as its counter productive results that may continuously happen and it is important to take interdependence model and to adopt combination of negotiation concepts of Rubin and Rubin (2006), Post (1990), and principled negotiation along with principles and ethics of negotiation. Moreover, socialisation of Permenaker Number 16 Year 2011 requires to be activated continuously and to revise related regulation in more appropriate. 
This article, despite contains concepts, model, principle, and negotiation position, there are at least 2 limitation namely: 1 these existing concepts in this paper explain types of negotiation for general organization and worker union, not only discussed specifically on negotiation in the worker union version; 2. The size of PUK is only amount to 2 organizations.

\section{REFERENCES}

Beil, Martin., Litscher, Jon E., 1998, Consensus Bargaining in Wisconsin State Government: A New Approach to Labour Negotiation, Public Personnel Management, Vol. 27, No. 1, pp 39-49

Brainerd, Richard., 1998, Interest-Based Bargaining: Labor and Management Working Together in Ramsey County, Minnesota, Public Personnel Management, Vol. 27, No. 1, pp 51-60

Budiarti, Indah., 2012, Perjanjian Kerja Bersama untuk Kesejahteraan Buruh

Caverley, Natasha., Cunningham, Bart., dan Mitchell, Lari., 2006, Reflections on Public Sector-based Integrative Collective Bargaining, Employee Relations, Vol. 28, No. 1/2, pp $62-74$

Donohue, William A., Roberto, Anthony J., 1996, An Empirical Examination of Three Models of Integrative and Distributive Bargaining, International Journal of Conflict Management, Vol. 7, No. 3, pp 209-229

Edralin, Divina M., 1999, Collective Bargaining Process and Its Outcome, CBE Working Series, Series 1999-03, De La Salle University, Philippines

Finishing Contractors Association and Allied Traders International Union, Tanpa Tahun, Guide Book for Collective bargaining Agreements in The Finishing Industries

Gatchalian, Jose C., 1998, Principled negotiations: a key to successful collective bargaining, Management Decision, Vol. 36, No. 4, pp. 222 - 225

Guntur, Agus., 2010, Strategi Negosiasi, , Makalah Program Magister Manajemen Semester I, MM STEKPI

Heldt, Eugenia da Conceicao., 2006, Integrative and Distributive Bargaining Situations in the European Union: What Difference Does It Make?, Negotiation Journal, Vol 22, No. 2, pp 145-165

Lens, Vicki., 2004, Principled Negotiation: A New Tool for Case Advocacy, Social Work, Vol. 49, No. 3, pp 506-513

Lobel, Ira B., 2000, Is Interest Based on Bargaining Really New?, Dispute Resolution Journal, Vol. 55, No. 1, pp 8-17

Paquet, Renaud., Gaetan, Isabell., Bergeron, Jean Guy., 2000, Does Interest-Based Bargaining (IBB) Really Make a Difference in Collective Bargaining Outcomes?, Negotiation Journal, Vol. 16, No. 3, pp 281-296

Peraturan Menteri Tenaga Kerja dan Transmigrasi Republik Indonesia Nomor PER. 16/MEN/XI/2011 tentang Tata Cara Pembuatan dan Pengesahan Peraturan Perusahaan serta Pembuatan dan Pendaftaran Perjanjian Kerja Bersama 


\section{Macrothink Institute ${ }^{T M}$}

Post, Frederick R., 1990, Collaborative Collective Bargaining: Toward an Ethically Defensible Approach to Labor Negotiations, Journal of Business Ethics, Vol. 9, No. 6, pp. 495-508

Provis, Chris., 2000, Ethics, Deception, and Labor Negotiation, Journal of Business Ethics, Vol. 28, No. 2, pp 145-158

Roose, Paul D., 2006, A Special Comment from A Conflict Management Practitioner: A Call for Research on Collaboration versus Traditional Bargaining in Labor-Management Relationships, International Journal of Conflict Management, Vol. 17, No. 4, pp. 352-355

Rubin, Barry., Rubin, Richard., 2006, Labor-Management Relations: Conditions for Collaboration, Public Personnel Management, Vol. 35., No. 4, pp. 283-298

Simanjuntak, Payaman J., 2009, Manajemen Hubungan Industrial, Edisi 2, Jala Permata Aksara, Jakarta 